\title{
Prediction of Heave from the CLOD Index for Natural and Contaminated Clay Soils from the Mazovia Area
}

\author{
Dorota Izdebska-Mucha, Emilia Wójcik* \\ Institute of Hydrogeology and Engineering Geology, Faculty of Geology, University of Warsaw, \\ Żwirki i Wigury 93, 02-089 Warszawa, Poland
}

Received: 20 January 2017

Accepted: 10 May 2017

\begin{abstract}
This paper deals with the prediction of free heave in expansive soils from central Poland. Thirty-nine soil samples differing in plasticity were selected for a comparative analysis. The soil types examined - Neogene clays, alluvial soils, and glacial tills - differ in CLOD index $\left(\mathrm{C}_{\mathrm{w}}\right)$ values, which range from 0.027 to 0.019 , with values for undisturbed samples being higher than those for the remoulded ones. The variability of the $\mathrm{C}_{\mathrm{w}}$ index correlates best with the sand-to-clay ratio. Studies of soils contaminated with diesel oil (ON) have revealed that the $\mathrm{C}_{\mathrm{w}}$ index decreases with growing $\mathrm{ON}$ content. Calculations of the potential heave, assuming a $1 \%$ moisture change for a $1 \mathrm{~m}$ thick soil layer, show the heave to be 18 to $12 \mathrm{~mm}$ and 15 to 11 $\mathrm{mm}$ for Neogene clays and glacial tills, respectively, depending on the in situ void ratio. Petroleum contamination significantly reduces the potential heave of the soil. The present analysis clearly suggests that glacial tills are more susceptible to oil-derived contamination than Neogene clays.
\end{abstract}

Keywords: soil contamination, cohesive soils, soil shrinkage, heave

\section{Introduction}

Evaluating volume changes in expansive soils is a crucial engineering problem. Soil expansiveness is controlled chiefly by regional geological background and post-genetic transformations due to natural factors and human impact. The swelling of highly plastic clays has resulted in severe damage to such lightly loaded structures as houses, warehouses, small industrial buildings, and pavement in several areas of the world [1-3]. Therefore, a proper evaluation of expansivity and determination

*e-mail: wojcike@uw.edu.pl of potential heave is of key significance in geotechnical design.

Heave prediction can be conducted in ways to imply various degrees of accuracy. Earlier methods predicted heave in terms of very high, high, medium, and low, and they were based on index soil parameters. Some of the most recognized empirical relationships for predicting heave came from liquid limit, plasticity index, clay content, initial water content, and dry density, along with depth of expansive layer and overburden load as summarized by [4-5]. A different approach to estimate heave values are analytical methods that use laboratory-measured specified parameters. They could be classified into two groups: methods based on oedometer tests and methods based on soil suction tests [6]. 
Table 1. Basic properties of the studied soils.

\begin{tabular}{|c|c|c|c|c|c|c|c|c|}
\hline Soil no & Soil type & $\begin{array}{c}\text { Specific } \\
\text { density } \\
\rho_{\mathrm{s}}\left(\mathrm{Mg} / \mathrm{m}^{3}\right)\end{array}$ & $\begin{array}{l}\text { Sand content } \\
\mathrm{Sa}(\%)\end{array}$ & $\begin{array}{l}\text { Silt content } \\
\text { Si }(\%)\end{array}$ & $\begin{array}{l}\text { Clay content } \\
\mathrm{Cl}(\%)\end{array}$ & $\begin{array}{c}\text { Shrinkage } \\
\text { limit } \\
\text { SL }(\%)\end{array}$ & $\begin{array}{l}\text { Plastic limit } \\
\text { PL (\%) }\end{array}$ & $\begin{array}{l}\text { Liquid limit } \\
\text { LL (\%) }\end{array}$ \\
\hline $\mathrm{C} 1$ & \multirow{26}{*}{$\begin{array}{l}\text { Neogene } \\
\text { clays }\end{array}$} & 2.72 & 2 & 18 & 80 & 13.5 & 41.0 & 96.0 \\
\hline $\mathrm{C} 2$ & & 2.69 & 8 & 20 & 72 & 13.8 & 35.0 & 83.0 \\
\hline $\mathrm{C} 3$ & & 2.71 & 0 & 37 & 63 & 12.3 & 22.5 & 69.5 \\
\hline $\mathrm{C} 4$ & & 2.70 & 13 & 57 & 30 & 13.8 & 39.3 & 69.9 \\
\hline $\mathrm{C} 5$ & & 2.70 & 1 & 29 & 70 & 14.2 & 31.3 & 70.1 \\
\hline C6 & & 2.72 & 0 & 20 & 80 & 16.0 & 30.3 & 83.0 \\
\hline $\mathrm{C} 7$ & & 2.71 & 4 & 31 & 65 & 14.0 & 32.3 & 99.0 \\
\hline $\mathrm{C} 8$ & & 2.71 & 0 & 10 & 90 & 19.0 & 43.6 & 91.7 \\
\hline C9 & & 2.68 & 4 & 34 & 62 & 12.0 & 27.6 & 68.2 \\
\hline $\mathrm{C} 10$ & & 2.69 & 3 & 36 & 61 & 13.0 & 25.4 & 64.4 \\
\hline $\mathrm{C} 11$ & & 2.72 & 2 & 18 & 80 & 13.5 & 41.0 & 96.0 \\
\hline $\mathrm{C} 12$ & & 2.69 & 8 & 20 & 72 & 13.8 & 35.0 & 83.0 \\
\hline $\mathrm{C} 13$ & & 2.71 & 0 & 37 & 63 & 12.3 & 22.5 & 69.5 \\
\hline $\mathrm{C} 14$ & & 2.72 & 4 & 28 & 68 & 14.7 & 41.1 & 81.0 \\
\hline $\mathrm{C} 15$ & & 2.73 & 5 & 32 & 63 & 12.2 & 36.9 & 77.2 \\
\hline $\mathrm{C} 16$ & & 2.69 & 18 & 51 & 31 & 13.9 & 24.6 & 48.0 \\
\hline $\mathrm{C} 17$ & & 2.67 & 10 & 57 & 33 & 14.6 & 24.1 & 45.2 \\
\hline $\mathrm{C} 18$ & & 2.66 & 2 & 18 & 80 & 11.1 & 38.3 & 104.1 \\
\hline $\mathrm{C} 19$ & & 2.68 & 6 & 31 & 63 & 11.6 & 27.0 & 76.9 \\
\hline $\mathrm{C} 20$ & & 2.66 & 9 & 31 & 60 & 11.4 & 26.1 & 68.0 \\
\hline $\mathrm{C} 21$ & & 2.81 & 1 & 11 & 88 & 9.1 & 28.6 & 78.9 \\
\hline $\mathrm{C} 22$ & & 2.79 & 0 & 17 & 83 & 11.3 & 30.5 & 69.6 \\
\hline $\mathrm{C} 23$ & & 2.80 & 0 & 27 & 73 & 10.4 & 29.3 & 68.1 \\
\hline $\mathrm{C} 24$ & & 2.77 & 3 & 27 & 70 & 5.1 & 19.6 & 54.4 \\
\hline $\mathrm{C} 25$ & & 2.78 & 4 & 29 & 67 & 7.2 & 18.9 & 52.8 \\
\hline $\mathrm{C} 26$ & & 2.66 & 1 & 14 & 85 & 16.5 & 33.8 & 87.0 \\
\hline G1 & \multirow{9}{*}{ Glacial tills } & 2.70 & 42 & 37 & 21 & 5.8 & 12.0 & 20.6 \\
\hline $\mathrm{G} 2$ & & 2.69 & 61 & 21 & 18 & 9.6 & 13.7 & 19.3 \\
\hline G3 & & 2.68 & 60 & 16 & 24 & 7.0 & 14.3 & 25.8 \\
\hline G4 & & 2.70 & 56 & 17 & 27 & 9.3 & 12.4 & 23.6 \\
\hline G5 & & 2.70 & 52 & 23 & 25 & 9.7 & 12.8 & 24.0 \\
\hline G6 & & 2.71 & 59 & 17 & 24 & 7.8 & 13.0 & 23.3 \\
\hline G7 & & 2.69 & 61 & 13 & 24 & 8.1 & 13.5 & 23.5 \\
\hline G8 & & 2.66 & 47 & 23 & 29 & 7.5 & 14.1 & 36.6 \\
\hline G9 & & 2.66 & 47 & 23 & 29 & 8.2 & 14.1 & 36.6 \\
\hline A1 & \multirow{4}{*}{ Alluvial soils } & 2.68 & 23 & 62 & 15 & 13.6 & 23.4 & 48.0 \\
\hline A2 & & 2.69 & 18 & 55 & 27 & 13.0 & 19.0 & 38.2 \\
\hline A3 & & 2.66 & 45 & 46 & 9 & 10.0 & 17.9 & 26.0 \\
\hline A4 & & 2.68 & 9 & 78 & 13 & 12.8 & 18.9 & 38.8 \\
\hline
\end{tabular}


Considering the significance of soil expansiveness for safe and effective soil management for engineering purposes, the main objective of this study is to predict the heave of natural and contaminated cohesive soils commonly occurring in the Mazovia region from shrinkage tests, according to the method proposed by Miller et al. [7]. Shrinkage limit and the CLOD index $\left(\mathrm{C}_{\mathrm{w}}\right)$ were determined for Neogene clays, glacial tills, and alluvial soils. The $\mathrm{C}_{\mathrm{w}}$ index variability was explored with respect to the selected index parameters of the soils as well as the soil structure (disturbed/undisturbed) and microstructure. Last but not least, the $\mathrm{C}_{\mathrm{w}}$ index and potential heave were determined for Neogene clays and glacial tills contaminated with diesel oil. The need to investigate contaminated soils results from the sustainable development of economic-industrial infrastructure and the growing use of liquid fuels, mainly oil-derived, which add to the progressing contamination and even degradation of the subsoil (e.g. [8-13]). A high percentage of the identified petroleum-contaminated sites has been localized around busy transport routes, which can be classified as lightly loaded structures.

This paper is a continuation of a previous study by the present authors [14] focused on prediction of heave based on suction measurements, and contributes to the examinations of contaminated soil properties and estimating expansive soil behaviour for typical clay soils widely occurring in Poland [15-21].

\section{Materials and Methods}

Expansive soils, widespread in Poland, are a common building foundation. Samples of natural soils, differing in genesis and lithology and representing a wide range of plasticity, have been selected for the present study: Neogene clays (Mio-Pliocene, samples C1-26), glacial tills (samples G1-9), and alluvial soils (samples A1-4). A total of 39 samples from various parts of the Mazovia area (Warsaw, Mszczonów, and Dobre) were examined. For all samples, the following basic parameters have been determined: grain size distribution, plastic limit, liquid limit (BS1377: Part 2: 1990 [22]), shrinkage limit (according to BS1377: Part 2: 1990 [22] and the CLOD test method), and specific density (a gas pycnometer method, AccuPyc 1330, Micromeritics, USA). The qualitative analysis of soil microstructure was performed using a Scanning Electron Microscope (JSM 6380 LA, Jeol, Japan).The basic soil parameters are summarized in Table 1. According to Casagrande nomogram, tills and alluvial soils have low to medium plasticity. Neogene clays can be classified into soils of medium to extremely high plasticity, thus occurring in the active zone and subjected to changing environmental conditions, they will exhibit volume deformations.

Laboratory tests for determining soil shrinkage have been completed in accordance with BS1377: Part 2: 1990 [22], as well as using the CLOD test method developed by [23]. Both methods are analogous and refer directly to the definition of the shrinkage limit after Casagrande. The difference between them lies only in the way volume is measured.

Volume measurements of soil samples conducted according to BS1377: Part 2: 1990 [22] requirements were made using a mercury apparatus (Wykeham Farrance WF 2/756, UK). However, due to high toxicity of mercury and restrictive laboratory safety rules, some of the tests were carried out using a GeoPyc 1360 pycnometer (Micrometrics, USA). In this apparatus a soil sample is analysed in a DryFlo ${ }^{\circledR}$ quasi-fluid displacement medium composed of microspheres with a high degree of flowability that do not wet the sample or fill its pores. This non-destructive test permits accurate repetitive measurements of the sample during the drying process. [24] proposed a similar method - the bead replacement method based on the use of spherical beads of an inert material of a uniform grain size. The results obtained were in good agreement with those from the conventional mercury displacement method.

The CLOD method is suitable for testing hard fractured soils or irregularly shaped specimens that can be easily obtained from the broken pieces. It consists in covering the sample with liquid resin (DOW Saran F310 resin diluted in methyl ethyl ketone at a powder:solvent ratio of 1:7), which acts like a delicate membrane adjusting to the shape of the sample. The resin protects the natural soil structure and allows volume measurements during slow air-drying. It permits a gradual release of vapour from soil, while in short contact with water it becomes impermeable. Volume is determined by weighing samples in distilled water following Archimedes Law.

The final outcome of the shrinkage measurement is the shrinkage curve, which serves to determine such parameters as shrinkage limit $\mathrm{w}_{\mathrm{s}}$ and CLOD index $\mathrm{C}_{\mathrm{w}}$ (Fig. 1). The CLOD index, characteristic of each type of soil, is defined by the slope of the void ratio-water content relationship that corresponds to the proportional shrinkage phase.

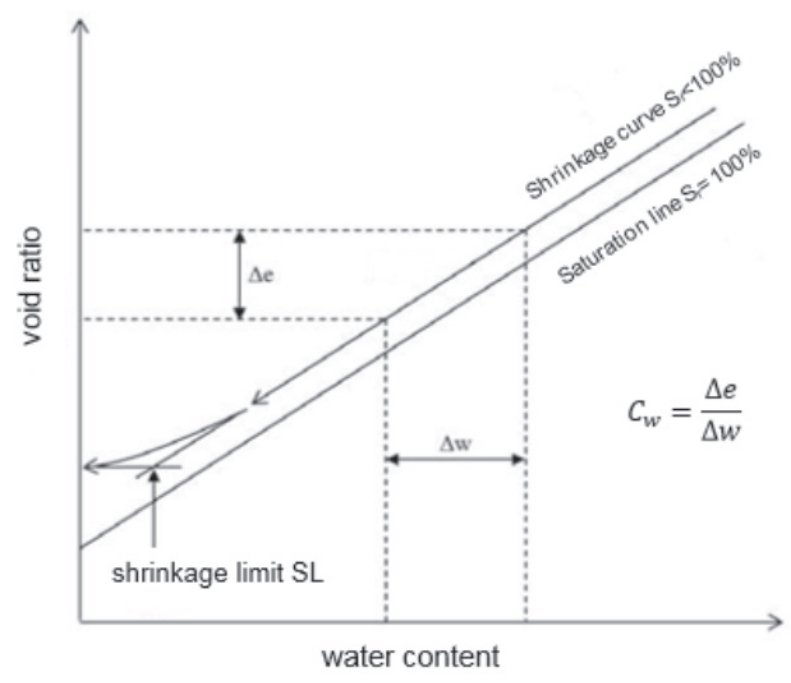

Fig. 1. CLOD test shrinkage curve. 
Miller et al. [7] proposed a method for predicting total heave based on CLOD index values. Total heave is the sum of heaves calculated for individual layers according to the equation:

$$
\rho=\sum_{i=1}^{n} \frac{\left(C_{w} \Delta w\right)_{i}}{\left(1+e_{0}\right)_{i}} z_{i}
$$

where:

$\rho$ is total heave [mm]

$C_{w}$ is CLOD index [-]

$\Delta w$ is change of moisture content in the soil layer [\%]

$z_{i}$ is thickness of the soil layer [mm]

$e_{0}$ is void ratio [-]

This method, however, does not consider net normal stress. Therefore, it is applicable only for determining free field heave or heave under very light loads such as pavements or floating floor slabs.

In the present study, this method was used to characterize the potential heave of Neogene clays and glacial tills from Poland with respect to the measured shrinkage characteristics of the considered soils. The heave was computed for a $1 \mathrm{~m}$ thick soil layer assuming a $1 \%$ change of moisture content. The following assumptions were made:

1. $\mathrm{C}_{\mathrm{w}}$ - average values were assumed from the measurements of the tested soil samples (see Fig. 4 and Table 2)

2. $e_{0}-$ several values of void ratio were assumed to reflect various conditions in the ground, for Neogene clays: $\mathrm{e}_{0}=0.50 ; 0.75 ; 1.00 ; 1.25$ and 0.67 which is the measured average in situ void ratio; for glacial tills: $\mathrm{e}_{0}=0.25 ; 0.50 ; 0.75$ and $0.40-$ the measured average in situ void ratio.

The influence of petroleum contamination on soil shrinkage was analyzed for Neogene clays and glacial tills. The soil samples passing through a 10-mesh sieve were oven-dried at $105^{\circ} \mathrm{C}$ and mixed with diesel oil (ON) in the amount of $0 \%, 4 \%, 8 \%, 12 \%$, and $16 \%$ by dry weight of the soil. They were kept in closed containers for three months to allow ageing and possible reactions between the pollutant and the soil. Then the equilibrated samples were mixed with distilled water in the amount corresponding to the plastic limit of the soil. The cylindrical specimens were prepared and the shrinkage tested according to BS1377: Part 2: 1990 procedure [22]. The void ratio was calculated with respect to the specific density of the contaminated soils. In the case of glacial tills, it was impossible to complete the measurements for samples containing $12 \%$ and $16 \%$ of diesel oil. Due to reduction of cohesiveness, the samples behaved like non-cohesive fine grained soils and disintegrated in the course of taking measurements.

\section{Results and Discussion}

A summary statistics of the CLOD index $\left(\mathrm{C}_{\mathrm{w}}\right)$ results for the remoulded soil samples are presented in Table 2 .
The study showed that $\mathrm{C}_{\mathrm{w}}$ for Neogene clays is within a narrow range of values $C_{w}{ }_{w}=0.024-0.029$ (mean 0.027). These results are in agreement with [20], who reported that the average CLOD index for Neogene clays from the Bydgoszcz area is 0.027 . Glacial tills exhibited a wider $\mathrm{C}_{\mathrm{w}}$ variation $\left(\mathrm{C}_{\mathrm{w}}=0.012-0.022\right)$, the mean being 0.019 . Alluvial soils, regardless of the compositional diversity within the tested sample set (see Table 1), showed a narrow range of $\mathrm{C}_{\mathrm{w}}$ values $\left(\mathrm{C}_{\mathrm{w}}=0.023-0.025\right.$; mean $0.024)$ similar to Neogene clays.

As is clear from previous studies, the soil shrinkage characteristics are controlled by soil plasticity and fabric (e.g. [18, 25-27]). In this study, the relationship between CLOD index and plasticity index, clay content, and the sand-to-clay ratio was analyzed. For selected soil samples, soil shrinkage values of undisturbed and remoulded soils were compared and discussed with respect to the soil microstructure.

Analysis of the data given in Figs. 2a-c indicates a strong and very strong correlation between $\mathrm{C}_{\mathrm{w}}$ and the considered index parameters. In all cases, the polynomial function best fits the given set of data. Higher values of correlation coefficients were obtained for undisturbed samples than for the remoulded ones. The sand-to-clay ratio best explains the $\mathrm{C}_{\mathrm{w}}$ variation $(70 \%$ and $80 \%$ for the remoulded and undisturbed samples, respectively). It is noteworthy that on each plot the best fit line for undisturbed samples is below that for the remoulded soils, which simply points to the lower values of $\mathrm{C}_{\mathrm{w}}$ noted in undisturbed soils. A deeper insight into this effect is given in Fig. 3. Double analysis of soil shrinkage for disturbed and undisturbed soil samples was carried out for five samples of Neogene clays (C1 to C5), two samples of glacial tills (T1, T2), and four samples of alluvial soil (A1 to A4). It has been found that for all soil types, $\mathrm{C}_{\mathrm{w}}$ achieves higher values for remoulded samples than for the undisturbed ones. In the case of Neogene clays the average difference is of $12 \%$, while for alluvial soils it ranges from $33 \%$ (A1) to $76 \%$ (A3) (mean 53\%). The possible reason of such discrepancies between the behaviour of Neogene clays and alluvial soils might be accounted for by the natural soil microstructure. The scanning electron microscope (SEM) analysis of the tested Neogene clays showed that they have a matrix-turbulent microstructure

Table 2. Summary statistics of CLOD index for the remoulded samples of the tested soils.

\begin{tabular}{|c|c|c|c|}
\hline & $\begin{array}{c}\text { Neogene } \\
\text { clays }\end{array}$ & $\begin{array}{c}\text { Glacial } \\
\text { tills }\end{array}$ & $\begin{array}{c}\text { Alluvial } \\
\text { soils }\end{array}$ \\
\hline Number of samples & 26 & 9 & 4 \\
\hline Mean & 0.027 & 0.019 & 0.024 \\
\hline Min & 0.024 & 0.012 & 0.023 \\
\hline Max & 0.029 & 0.022 & 0.025 \\
\hline Median & 0.027 & 0.020 & 0.024 \\
\hline Standard deviation & 0.00164 & 0.0029 & - \\
\hline
\end{tabular}



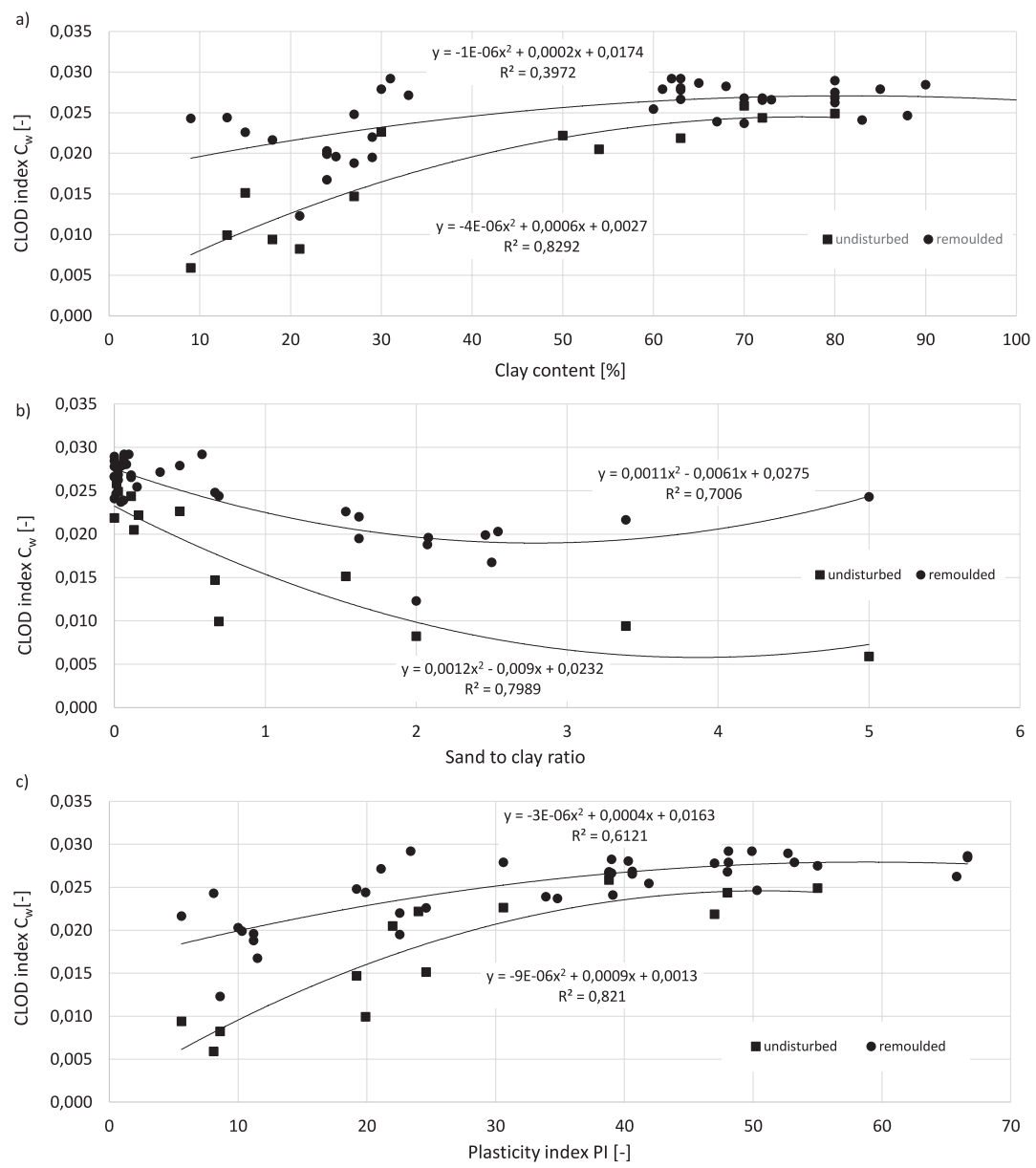

Fig. 2. Variation of CLOD index $\mathrm{C}_{\mathrm{w}}$ with: a) clay content, b) sand to clay ratio, and c) plasticity index PI.

that is characteristic of this soil type [28], while the alluvial soils showed a matrix-skeletal microstructure. The micrographs of the undisturbed samples of the Neogene clays and alluvial solids are presented in Figs. $4 a-b$. The transformation of natural microstructure of alluvial soils in remoulded samples and the disintegration of natural bonds between the structural elements promotes different patterns of solids arrangement in the process of shrinkage. A disturbed fabric with a high content of silt

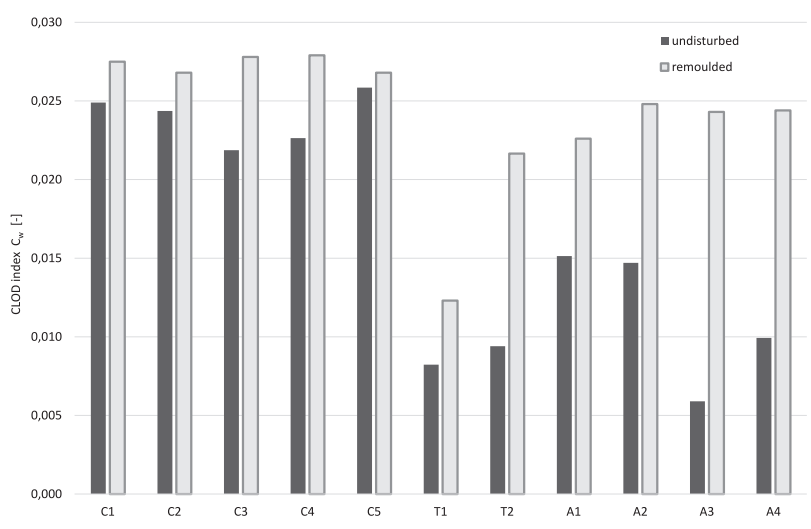

Fig. 3. Comparison of CLOD index $\mathrm{C}_{\mathrm{w}}$ for undisturbed and remoulded specimens. and sand (skeletal microstructure) strongly promotes denser packing of solids, which in turn leads to a steeper shrinkage curve and higher CLOD index values. These findings must be considered preliminary due to the small number of samples, and require further investigation.

The results of shrinkage examinations of soils contaminated with diesel oil (ON) are presented in Fig. 5. Although they generally show a reduction of CLOD index values with the increasing $\mathrm{ON}$ content, for Neogene clay the tendency is non-uniform $\left(\mathrm{C}_{\mathrm{w}}=0.028 ; 0.024 ; 0.026\right.$ for 0,8 , and $16 \% \mathrm{ON}$, respectively). This reduction is faster for glacial till $\left(\mathrm{C}_{\mathrm{w}}=0.021 ; 0.012\right.$ for 0 and $8 \% \mathrm{ON}$, respectively), which, in addition to the loss of cohesion in more contaminated samples, proves a higher susceptibility of glacial tills to petroleum contamination.

The free field heave values were calculated for Neogene clays and glacial tills for both uncontaminated (Fig. 6) and contaminated soils (Fig. 7). Considering the assumptions made, it was found that the heave of Neogene clay is about $18 \mathrm{~mm}$ to $12 \mathrm{~mm}$, depending on the initial void ratio (e $=0.5$ to 1.25 , respectively). For glacial tills the predicted heave ranges from about $15 \mathrm{~mm}$ to $11 \mathrm{~mm}(\mathrm{e}=0.25$ to 0.75 , respectively). For a given soil, the increase of void ratio corresponds to increasing moisture content, which in turn results in a decrease of potential heave of the soil. It was also found that petroleum contamination significantly 

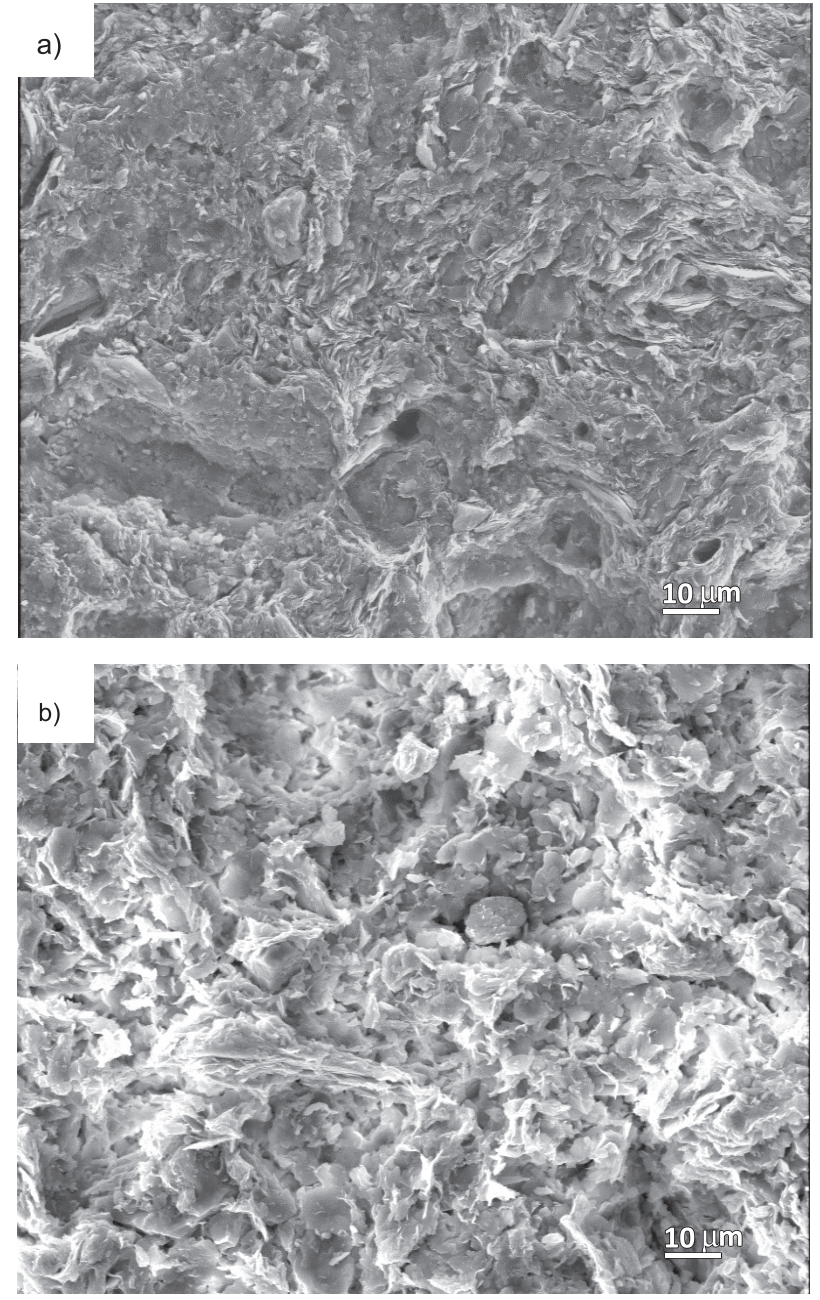

Fig. 4. SEM micrographs of: a) Neogene clays and b) alluvial soils (magnification $800 x$ ).

reduces the potential heave of the soil (Figs. 7a-b). The variability of results is parallel to the $\mathrm{C}_{\mathrm{w}}$ changes. For both Neogene clays and glacial tills, the lowest values of heave were obtained for $8 \%$ ON samples $(\rho=16-11 \mathrm{~mm}$ and $\rho=11-7 \mathrm{~mm}$, respectively). Preparation of test samples

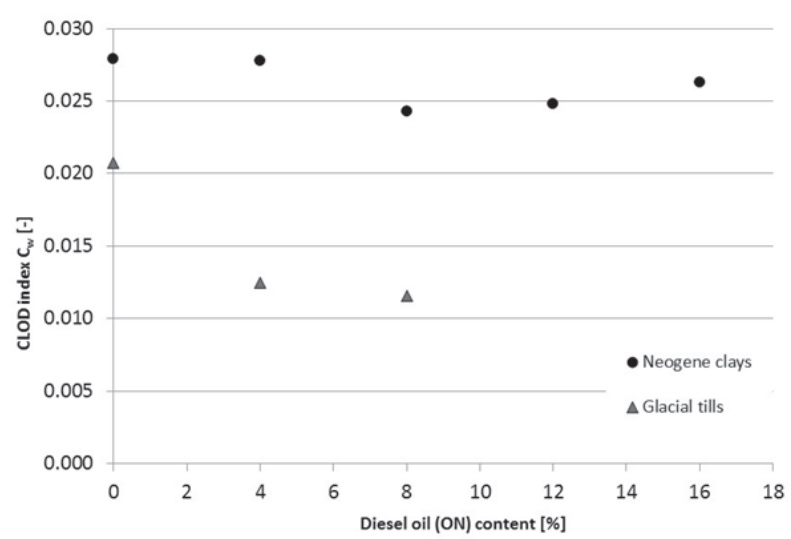

Fig. 5. Influence of diesel oil (ON) on CLOD index $\mathrm{C}_{\mathrm{w}}$ of Neogene clays and glacial tills.

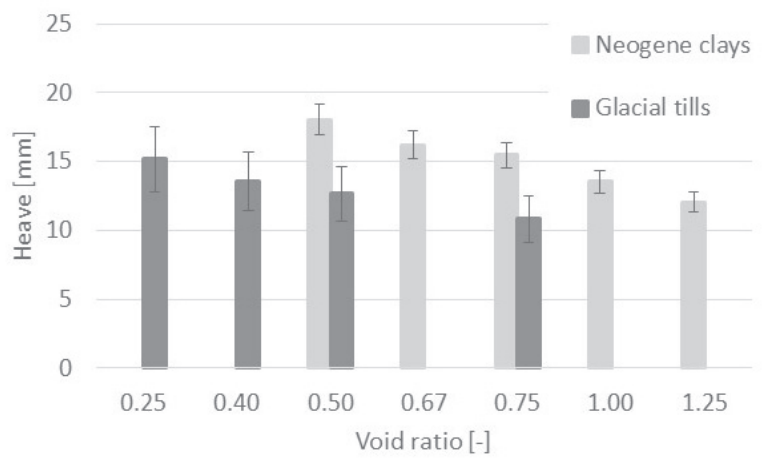

Fig. 6. Prediction of potential heave of Neogene clays and glacial tills.

by mixing diesel oil with dry soils allows the results to simulate the effect of long-term contamination, where the pollutant gets into immediate contact with the soil particles. The assembled data provide a basis for heave prediction for any assumed change of soil moisture content and thickness of the soil layer by simple multiplying the values presented herein according to the equation given in [7]. Due to a high homogeneity of the CLOD index of Neogene clays, the outcome of this study seems especially valuable for predicting heave for this type of soil. The method here described is another approach (compare [14]) to estimating expansive soil behaviour of typical clay soils widely occurring in Poland, differing in genesis and compositional characteristic. According to some
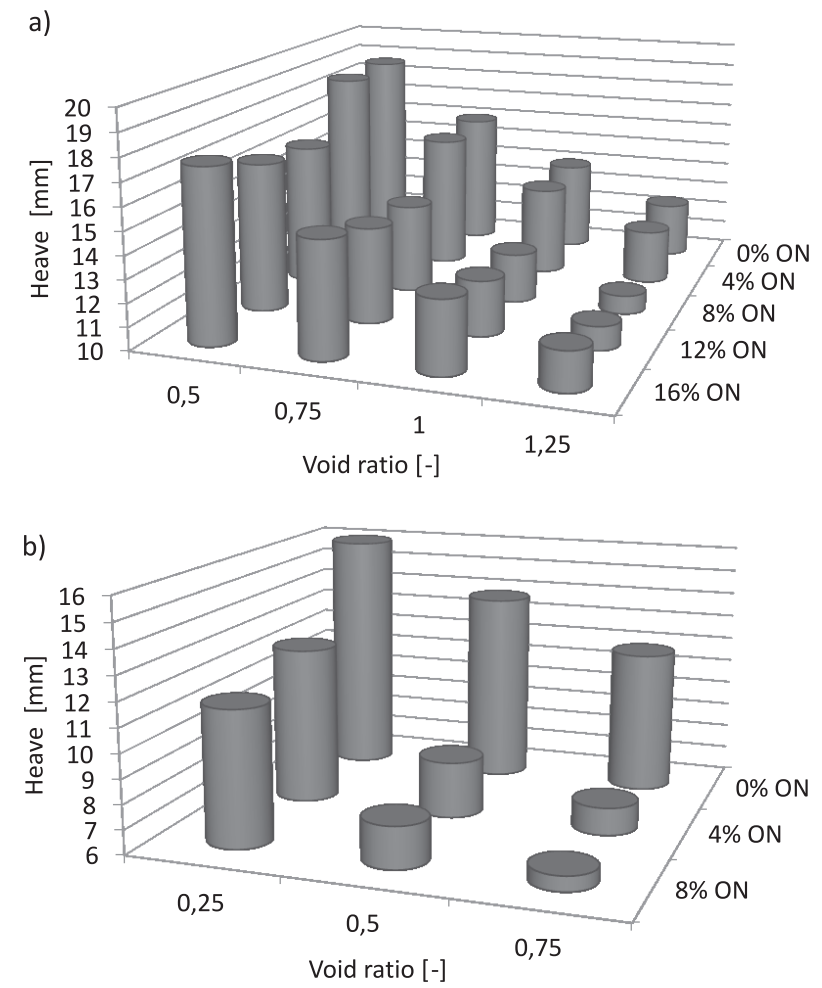

Fig. 7. Prediction of potential heave of soils contaminated with diesel oil (ON): a) Neogene clays and b) glacial tills. 
authors, soil shrinkage characteristics are not suitable for predicting soil behaviour related to swelling. [25] showed that shrinkage is a function of grain size distribution and fabric, irrespective of the plasticity of the soil. Based on field and laboratory investigations of Neogene clays from the Bydgoszcz area, [20] reported that $\mathrm{C}_{\mathrm{w}}$ depends on the range of changes in the soil moisture content, thus it cannot be used to estimate soil heave.

\section{Conclusions}

An experimental study was carried out to determine the shrinkage characteristics and the potential heave of natural and diesel oil-contaminated cohesive soils commonly occurring in the Mazovia region. The results showed that the average values of the CLOD index $\mathrm{C}_{\mathrm{w}}$ for Neogene clays, glacial tills, and alluvial soils are: $0.027 \pm 0.0016$, $0.019 \pm 0.0029$, and 0.024 , respectively. The correlation of $\mathrm{C}_{\mathrm{w}}$ and selected index parameters showed that the sand-toclay ratio best explains $\mathrm{C}_{\mathrm{w}}$ variability.

It was also revealed that $\mathrm{C}_{\mathrm{w}}$ achieves higher values for remoulded samples than for the undisturbed ones. The lowest difference has been found for Neogene clays and the highest for alluvial soils, which could be attributed to the difference in the natural microstructure between the considered soil types. The free field heave has been calculated according to the method given in [7], assuming $1 \mathrm{~m}$ thick soil layer and $1 \%$ change of soil moisture content, which provides a basis for heave prediction for any assumed change of environmental variables. It has been predicted that the heave of Neogene clay is about 18$12 \mathrm{~mm}$ and for $\mathrm{e}_{0}=0.5-1.25$, whereas for glacial tills it is $15-11 \mathrm{~mm}$ for $\mathrm{e}_{0}=0.25$ to 0.75 .

The examinations of diesel oil-contaminated Neogene clays and glacial tills have revealed the reduction of $\mathrm{C}_{\mathrm{w}}$ and the potential heave due to contamination. The lowest values have been noted for $8 \%$ ON samples, for which the heave ranges $16-11 \mathrm{~mm}$ for clays and 11-7 $\mathrm{mm}$ for tills, depending on the initial void ratio. The higher rate of changes in $\mathrm{C}_{\mathrm{w}}$ and heave values in function of soil contamination was obtained for glacial tills than Neogene clays, which suggests higher susceptibility of glacial tills to petroleum contamination.

\section{References}

1. LI J., DONALD A., CAMERON D.A., REN G. Case study and back analysis of a residential building damaged by expansive soils. Computers and Geotechnics 56, 89, 2014.

2. SAWANGSURIYA A., JOTISANKASA A., VADHANABHUTI B., LOUSUPHAP K. Identification of potentially expansive soils causing longitudinal cracks along pavement shoulder in central Thailand. Unsaturated Soils: Theory and Practice 2011 Jotisankasa, Sawangsuriya, Soralump and Mairaing (Editors) Kasetsart University, Thailand, ISBN 978-616-7522-77-7, 693, 2011.

3. SUDJIANTO A.T., SURYOLELONO K.B., RIFA A. AND MOCHTAR I.B. The effect of water content change and variation suction in behavior swelling of expansive soil. International Journal of Civil and Environmental Engineering, 11 (3), 11, 2011.

4. ELBADRY H. Simplified reliable prediction metod for determining the volume change of expansive soils based on simply physical tests. Housing and Building National Research Center HBRC Journal. 2016. http://dx.doi. org/10.1016/j.hbrcj.2015.10.001

5. ERZIN Y., GUNES N. The unique relationship between swell percent and swell pressure of compacted clays. Bull Eng Geol Environ 72, 71, 2013.

6. ARAFAT H., EBID A. Optimum replacement depth to control heave of swelling clays, International Journal of Engineering and Innovative Technology, 4, (9), 73, 2015.

7. MILLER D.J., DURKEE D.B., CHAO K.C., NELSON J.D. Simplified heave prediction for expansive soils. [In:] Alonso E.E. \& Delage P. (eds) Proceedings $1^{\text {st }}$ Intern. Conference "Unsaturated Soils", Paris, 2, 891, 1995.

8. ZULFAHMI A.R., UMAR H.M.,. MOHD RAIHAN T., NORSHEILA S.I., NOORULAKMA A. Influence of oil contamination on geotechnical properties of basaltic residual soil. American Journal of Applied Sciences, 7 (7), 954, 2010.

9. IZDEBSKA-MUCHA D., TRZCIŃSKI J. Microstructural properties of alluvial clayey soils polluted with petroleum fuels for a long period of time. Biuletyn PIG, 446 (2), 469, 2011 [In Polish].

10. KERMANI M., EBADI T. The effect of oil contamination on the geotechnical properties of fine-grained soils. Soil Sediment Contam. 21, 655, 2012.

11. WALIA B.S., SINGH G., KAUR M. Study of diesel contaminated clayey soil. Proceedings of Indian Geotechnical Conference, December 22-24, 2013.

12. ECHEVERRI-RAMÍREZ Ó., VALENCIA-GONZÁLEZ Y., TOSCANO-PATIÑO D.E., ORDOÑEZ-MUÑOZ F.A., CRISTINA ARANGO-SALAS C., OSORIO-TORRES S. Geotechnical behavior of a tropical residual soil contaminated with gasoline. DYNA, 82 (190), 31, 2015.

13. KHALED M. GHANEM, SALEH M. AL-GARNI, MAJID A. AL-ZAHRANI Bioremediation of diesel fuel by fungal consortium using statistical experimental designs. Pol. J. Environ. Stud. 25 (1), 97, 2016.

14. IZDEBSKA-MUCHA D., WÓJCIK E. Evaluation of expansivity of Neogene clays and glacial tills from central Poland on the basis of suction tests. Geological Quarterly, 59 (3), 593, 2015.

15. IZDEBSKA-MUCHA D., SZYSZKO, C., TRZCIŃSKI J. Engineering-geological and microstructural properties of glacial tills polluted with petroleum substances. Biuletyn PIG, 446 (2), 459, 2011 [In Polish].

16. IZDEBSKA-MUCHA D., WÓJCIK E. Analysis of clay soils shrinkage parameters according to various method. Biuletyn PIG, 446 (2), 321, 2011 [In Polish].

17. IZDEBSKA-MUCHA D., WÓJCIK E. Evaluation of the shrinkage and liquidity limits tests using statistical methods, Inżynieria Morska i Geotechnika, 6, 707, 2012 [In Polish].

18. IZDEBSKA-MUCHA D., WÓJCIK E. Testing shrinkage factors - comparison of methods and correlation with index properties of soils, Bulletin of Engineering Geology and the Environment, 72, 15, 2013.

19. IZDEBSKA-MUCHA D., WÓJCIK E. The influence of soil structure on clay soil shrinkage. Przegląd Geologiczny, 61, (3), 195, 2013. [In Polish].

20. KUMOR M.K. Expansive clay of building ground in Bydgoszcz. Some geotechnical problems. Wydawnictwa Uczelniane UTP w Bydgoszczy. 235, 2016 [In Polish]. 
21. NIEDŹWIEDZKA K., GARBULEWSKI K., LENDOSIWICKA M. Prediction of free field heave using $\mathrm{C}_{\mathrm{w}}$ and $\mathrm{C}_{\mathrm{H}}$ indices Annals of Warsaw University of Life Sciences SGGW Land Reclamation, 48 (1), 5, 2016.

22. BS1377: Part 2: Methods of testing soils for civil engineering purposes. British Standards Institution, London, 1990.

23. HAMBERG D. A simplified method for predicting heave in expansive soils. Master Thesis. Colorado State University, Fort Collins, Colorado. 1985

24. PRAKASH K., SRIDHARAN A. Use of uniform and inert beads for the determination of shrinkage limit of fine grained soils, Geotechnical and Geological Engineering, 30 (5), 1271-1278. ISSN 0960-3182, 2012.
25. SRIDHARAN A., PRAKASH K. Mechanism controlling the shrinkage limit of soils. Geotechnical Testing Journal GTJODJ 21 (3), 240, 1998.

26. GRAY C.W., ALLBROOK R., Relationships between shrinkage indices and soil properties in some New Zealand soils, Geoderma, 108, 287, 2002.

27. ZOLFAGHARI Z., MOSADDEGHI M.R., AYOUBI S. Relationships of soil shrinkage parameters and indices with intrinsic soil properties and environmental variables in calcareous soils, Geoderma, 277, 23, 2016.

28. KACZYŃSKI R. Overconsolidation and microstructures in Neogene clays. Geological Quarterly, 47 (1), 43, 2003. 